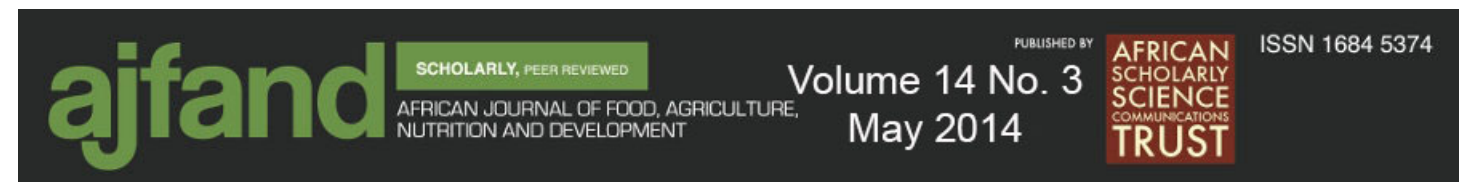

\title{
PHYSIO-CHEMICAL, MINERAL COMPOSITION AND ANTIOXIDANT PROPERTIES OF ROSELLE (HIBISCUS SABDARIFFA L.) EXTRACT BLENDED WITH TROPICAL FRUIT JUICES
}

\author{
Mgaya Kilima $\mathrm{B}^{1 \& 3^{*}}$, Remberg $\mathrm{SF}^{2},{\mathrm{Chove} \mathrm{BE}^{3} \text { and } \mathrm{T} \text { Wicklund }}^{1}$
}

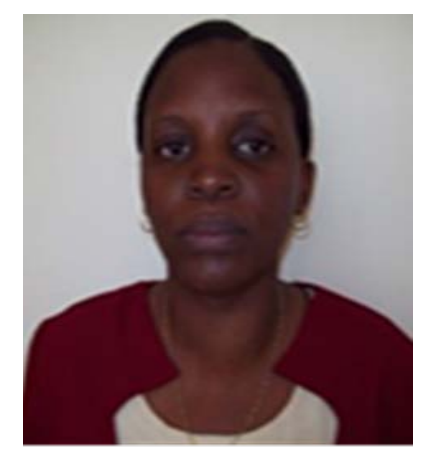

Beatrice Kilima Mgaya

*Corresponding author’s email: dukile@yahoo.com

${ }^{1}$ Norwegian University of Life Sciences, Department of Chemistry, Biotechnology and Food Science, P.O. Box 5003, 1432 Ås, Norway

${ }^{2}$ Norwegian University of Life Sciences, Department of Plant and Environmental Sciences, P.O. Box 5003, 1432 Ås, Norway

${ }^{3}$ Sokoine University of Agriculture, Department of Food Science and Technology, Faculty of Agriculture P. O Box 3006, Morogoro, Tanzania. 


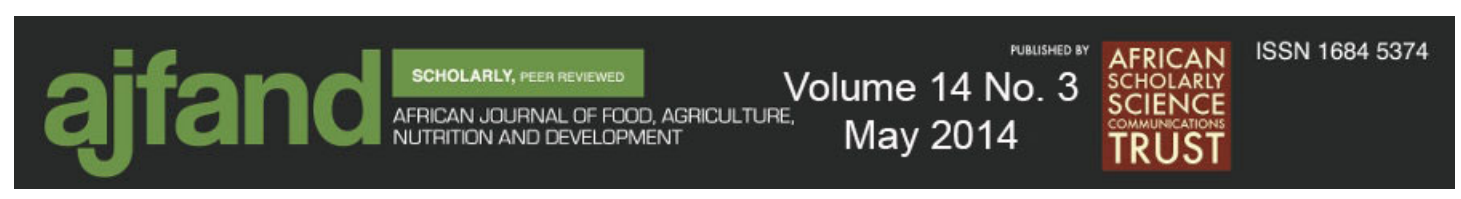

\section{ABSTRACT}

Different varieties of fruit juices and beverages are available globally and there has been an increased consumption of fruit juices and beverages due to consumer awareness of nutritional and health benefits. Juice extracts are produced from various parts of plants including leaves, fruits and flowers. Hibiscus sabdiriffa (Roselle) is one such plant whose flowers are used to prepare juices. The roselle extract has a unique red colour, good flavour, low sugar and high acidic content. The acidity makes the juice sour hence the need for addition of sweetening products. A study was conducted on the formulation of roselle extract-tropical fruit blends aimed at establishing its physiochemical, mineral and antioxidant composition. Dried roselle calyces at a ratio of $1: 10$ (dried roselle calyces: water) were extracted at $50^{\circ} \mathrm{C}$ for 30 minutes. The roselle extracts were blended at various proportions of fruit (mango, papaya and guava) juices. Physiochemical, mineral composition and antioxidant properties were evaluated in all the roselle fruit juice blends The results for all rosellefruit blends ( $80 \%$ roselle to $20 \%$ roselle) showed that $\mathrm{pH}$ ranged between (2.35-3.32), total soluble solids (5.6-10.6 ${ }^{\circ}$ Brix), titratable acidity (1.28-1.92 \%), reducing sugars (2.95-5.55) mg/100g, Calcium (555.3-23.4 mg/100g DM), Magnesium (213.8-11.5 mg/100g DM), Phosphorus (39.8-9.0 mg/100g DM), Sodium (2.3-5.47 mg/100g DM), Zinc (5.85-0.69 mg/100g DM), Iron (29.5-1.36 mg/100g DM), monomeric anthocyanin (493.5-118.2 mg cyanidin-3-glucoside/100g), vitamin C (40.0-86.5 $\mathrm{mg} / 100 \mathrm{~g})$, total phenol (54.6-10.8 mg gallic acid/ $100 \mathrm{~g}$ ) and antioxidant activity (1.80-1.37 mmol/L). Blending of tropical fruit juices with roselle extract have improved mineral composition and antioxidant properties of fruit juices as roselle is a good source of calcium, magnesium and iron. Antioxidants acts as free radical scavengers inhibit lipid peroxidation and other free radical mediated process, therefore, consumption of roselle-fruit juices with high anthocyanin will protect human body from several diseases attributed to the reactions of free radicals.

Key words: Roselle, Fruit juice, Antioxidants, Minerals 


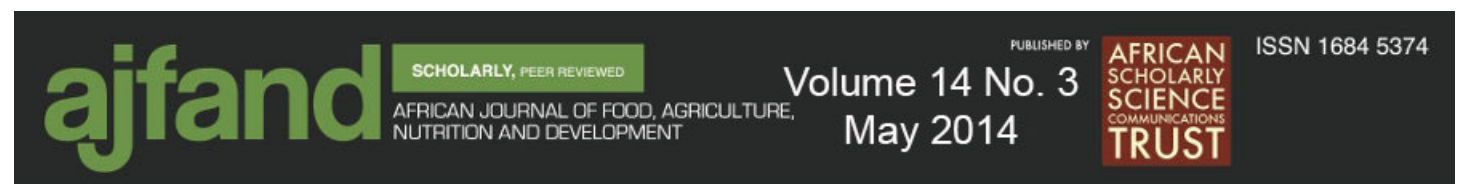

\section{INTRODUCTION}

There has been a global increase in consumption of fruit juice as consumers became aware of nutritional and health benefits of fruit juices [1]. The increased consumption of fruit juices goes together with increased variety of fruit juices and beverages offered for sale. Juicy extracts are produced from various types of plants especially their leaves, flowers of plants and fruits. Hibiscus sabdiriffa, commonly known as Roselle is one such plant whose flowers are used to prepare juices [2]. Roselle juice is also known as hibiscus tea, bissap, agua de Jamaica, Lo-Shen, red sorrel, sudan tea, sour tea or karkadè, is widely grown in Africa, South East Asia, and some tropical countries of America [3, 4]. Roselle produces red edible calyces with unique brilliant red colour, when extracted $[3,5]$.

Anthocyanins present in roselle are dephinidin 3-sambubioside, cyanidin 3sambubioside, delphinidin 3-glucoside and cyanidin 3-glucoside [1,6]. They contribute benefit for health as a good source of antioxidants as well as a natural food colorant [7]. Due to high acidity, bitterness and astringency nature, the beverage made from Roselle extract is not well accepted by a large proportion of consumers in Tanzania. Therefore, blending of Roselle extract with other tropical fruit juices such as mango, guava and papaya can improve aroma, taste and nutrients of the beverages.

Guava (Psidium guajava L.) belongs to the family Myrtaceae, commonly known as apple of the tropics. It grows well in tropical and subtropical regions. It is rich in ascorbic acid, contains almost five times as much vitamin $C$ as oranges [8, 9, 10]. Most of the guava produced around the world is consumed fresh.

Papaya (Carica papaya L.) is grown in every tropical and subtropical country. It has a pulpy flesh yellow or orange coloured with shades of yellow and red, depending on the fruit variety. It has the flavour of a cantaloupe; sweet and juicy with some muskiness [11]. The fruits have high contents of vitamin A, C and iron [12].

Mango is the most important and widely cultivated fruit in tropical and sub-tropical country [13] and is the king of the tropical fruit [14]. The mango fruit is an excellent source of fibre, vitamins A, C and the B complex, iron and phosphorus.

The blending of roselle juice with tropical fruit juices is anticipated to give products with high nutritional value and functional activity. The present study was aimed at assessing the possibility of blending roselle juice with three other fruit juices (guava, papaya and mango) to increase the utilization and establishing the nutritional composition of roselle-fruit juice.

\section{MATERIALS AND METHODS}

\section{Raw materials}

Dark red dried roselle calyces were purchased from the municipality market in Morogoro. Guava pink variety, papaya yellow variety and mango were purchased from horticulture garden at Sokoine University of Agriculture, Tanzania. 


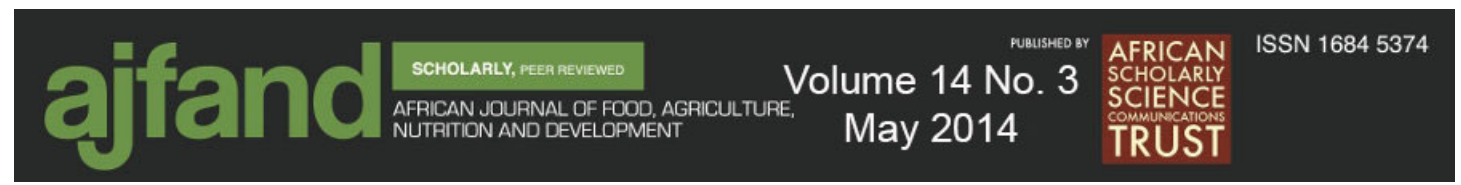

\section{Preparation of roselle extract}

Dried roselle calyxes (10\% moisture content) were ground for 1 minute using a blender (Kenwood BL 440, France). Grounded roselle calyces at a ratio of 1:10 (dried roselle calyces: water) were extracted using water bath at $50^{\circ} \mathrm{C}$ for 30 minute [15]. Roselle extracts were filtered with cheesecloth.

\section{Fruit juice preparation}

Fully matured and high quality fruits of mango, papaya and guava were used. Fresh mango papaya and guava were thoroughly washed, peeled and cut into small pieces (guava were not peeled). Then the small pieces were transferred to the juice extractor (Kenwood JE 810 UK) to obtain juice.

\section{Preparation of roselle-fruit juice blends}

Roselle-mango, roselle-papaya and roselle-guava were formulated in the ratio of 100:0, 80:20, 60:40, 40:60, 20:80 and 0:100 roselle extract: fruit juice pulp respectively. Sodium benzoate $(1 \mathrm{~g} / \mathrm{L})$ and citric acid $(1 \mathrm{~g} / \mathrm{L})$ were added to all roselle-fruit blends as preservatives. The juices were filled in $100 \mathrm{~mL}$ sterilized plastic bottles, loosely capped and pasteurized in a water bath at a temperature of $82.5^{\circ} \mathrm{C}$ for 20 min and cooled rapidly to room temperature by immersing the bottles in water bath $\left(28^{\circ} \mathrm{C}\right)$. Samples were drawn for chemical analyses.

\section{The $\mathbf{p H}$, titratable acidity and total soluble solids}

The $\mathrm{pH}$, titratable acidity (TA) and total soluble solids (TSS) of roselle-fruit blends were determined according to AOAC [16]. The $\mathrm{pH}$ was measured using Hanna portable $\mathrm{pH}$ meter (HI9125, Romania). TA was determined using 0.1N Sodium Hydroxide and phenolphthalein as an indicator and was expressed as \% malic acid and TSS was measured with a hand refractometer (Mettler Toledo, Switzerland) and expressed as Brix.

\section{Colour measurements}

The colour for Roselle fruit blends were measured using colour chart (Natural Colour system [NCS],Stockholm Sweden) followed by measuring the standard colour with a Chroma Meter Minolta CR- 400/410 (Minolta Co., Osaka, Japan) with the reflectance mode with $\mathrm{D}_{65}$ illuminant and $2^{\circ}$ observer angle. Samples were measured against a white ceramic reference plate

$\mathrm{C}\left(\mathrm{L}^{*}=94.0, \mathrm{a}^{*}=0.3138, \mathrm{~b}^{*}=0.3199\right) \mathrm{D} 65\left(\mathrm{~L}^{*}=94.0, \mathrm{a}^{*}=0.3163, \mathrm{~b}^{*}=0.3327\right)$

Colour values were expressed as $\mathrm{L}^{*}$ (whiteness or brightness/darkness), $\mathrm{a}^{*}$

(redness/greenness) and $\mathrm{b}^{*}$ (yellowness/blueness)

\section{Reducing sugars}

Reducing sugars were determined by Luff-Schoorl method as described by Egan et al. [17]. Sugar content was then determined by interpolation in a table (Egan et al.,) after subtracting the blank assay of the volume of sodium thiosulphate of the titration. The results where expressed in $\mathrm{mg} / 100 \mathrm{~g}$. 


\section{Minerals analysis}

Five gram of roselle-fruit blends were separately weighed into crucibles and dry ashed in muffle furnace maintained at $550^{\circ} \mathrm{C}$ for $2 \mathrm{hr}$. The ash was cooled in desiccators and then weighed. After weighing, the ash was dissolved in a solution of 1:1 ratio of H2O: $\mathrm{HCl}$, in which the concentration of the final mixture was $6 \mathrm{NHCl}$. Determination of calcium, magnesium, iron, zinc, phosphorus and copper content of the samples was carried out by AOAC method No 968.08 using atomic absorption spectrophotometer (Shimadzu UNICAM 919, Cambridge, UK) [16]. Two replicates were analyzed for each sample.

\section{Vitamin C assay}

Vitamin $\mathrm{C}$ content for the roselle fruit juices was determined according to the FolinCiocalteu reagent (FCR) method [18]. A 20mL of sample was pipetted into $100 \mathrm{~mL}$ volumetric flask followed by $2 \mathrm{~mL}$ of $10 \%$ TCA solution and diluted to $100 \mathrm{~mL}$ with distilled water. The sample was poured into a conical flask, swirled gently for 1 minute and left to stand for 1 minute and filtered with Whatman filter (no 542). One $\mathrm{mL}$ of the sample and $1 \mathrm{~mL}$ of standard solution (3 mg ascorbic acid in $1 \mathrm{~mL}$ distilled water) was pipetted into a test tube followed by $3 \mathrm{~mL}$ distilled water and $0.4 \mathrm{~mL}$ of Folin reagent. Mixing followed and thereafter the mixture was incubated at room temperature for $10 \mathrm{~min}$. The absorbance was read at $760 \mathrm{~nm}$ using Jenway 6405 UV/VIS Spectrophotometer, UK. The results were expressed in mg per $100 \mathrm{~g}$ fresh weight.

\section{Determination of antioxidant activity}

The antioxidant activity for the Roselle fruit blends was determined by the ferric reducing ability of plasma (FRAP) assay with some modifications [19]. Three $\mathrm{mL}$ of freshly prepared FRAP solution $(0.3 \mathrm{M}$ acetate buffer $(\mathrm{pH} 3.6)$ containing $10 \mathrm{mM}$ 2,4,6-tripyridyl-s-triazine (TPTZ) in $40 \mathrm{mMol} \mathrm{HCl}$ and $20 \mathrm{mM} \mathrm{FeCl}_{3} .6 \mathrm{H}_{2} \mathrm{O}$ ) and 100 $\mu \mathrm{L}$ of sample (standard) was incubated at $37^{\circ} \mathrm{C}$ for $4 \mathrm{~min}$ and the absorbance was measured at $593 \mathrm{~nm}$ using spectrophotometer. An intense blue colour was formed when the ferric-tripyridyltriazine $\left(\mathrm{Fe}^{3+-} \mathrm{TPTZ}\right)$ complex is reduced to the ferrous $\left(\mathrm{Fe}^{2+}\right)$ form at $593 \mathrm{~nm}$. A range of iron sulphate concentrations from 0.25 to 2.0$\mathrm{mMol} / \mathrm{L}$ was used to prepare the calibration curve. The results were expressed as millimoles of $\left(\mathrm{Fe}^{2+}\right)$ per liter of fresh weight $\left(\mathrm{mg}\left(\mathrm{Fe}^{2+}\right) / \mathrm{L} \mathrm{FW}\right)$.

\section{Total phenolics assay}

Total polyphenols content (TPC) for the Roselle fruit blends was determined according to the Folin-Ciocalteu method [20] with modifications. An aliquot of 300 $\mu \mathrm{L}$ sample solution was mixed with $1.5 \mathrm{~mL}$ of Folin-Ciocalteu's reagent (diluted 10 times), and $1.2 \mathrm{~mL}$ of sodium carbonate $(7.5 \% \mathrm{w} / \mathrm{v})$. After incubation at room temperature for $30 \mathrm{~min}$ in the dark, the absorbance was measured at $765 \mathrm{~nm}$ using spectrophotometer. Gallic acid (0-500 mg/100g) was used for calibration of a standard curve. The results were expressed as milligrams of gallic acid equivalents per $100 \mathrm{~g}$ of fresh weight (mg GAE/100 g FW). 


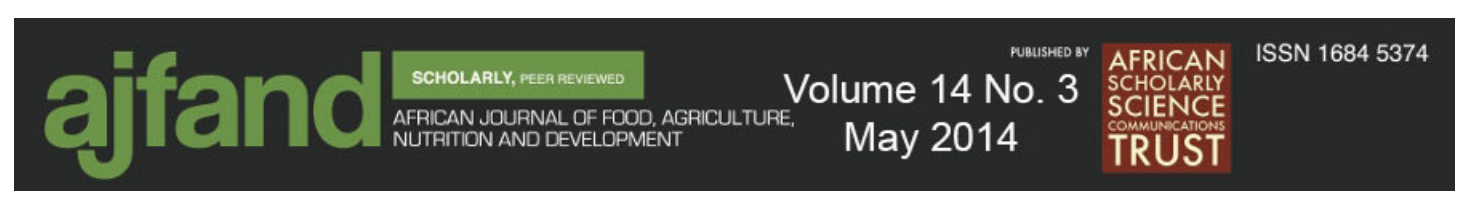

The total monomeric anthocyanin content (TMA)

The total monomeric anthocyanin content for roselle-fruit blends was carried out using the $\mathrm{pH}$ differential method [21]. Absorbance was measured at 520 and $700 \mathrm{~nm}$ using spectrophotometer.

The absorbance $(A)$ of the sample was then calculated according the following formula:

$A=\left(A_{520}-A_{700}\right)$ PH 1.0- (A520-A700) PH4.5

The monomeric anthocyanin pigment content in the original sample was calculated according the following formula:

$\mathrm{AC}=\underline{\mathrm{A} \times \mathrm{MW} \times \mathrm{DF} \times 1000}$

$\varepsilon \mathrm{L}$

Where, A- difference of sample absorbance between $\mathrm{pH} 1.0$ and 4.5 , $\varepsilon$ - molar extinction coefficient for cyanidin-3-glucoside (26,900); L- path length of the spectrophotometer cell $(1.0 \mathrm{~cm})$, DL- dilution factor and molecular weight (MW) of cyanidin-3- glucoside (449.2 g/mol), 1000- factor for conversion from $\mathrm{g}$ to $\mathrm{mg}$. The result was expressed as mg cyanidin-3-glucoside equivalent/100 g extract.

\section{Data Analyses}

All the results were expressed as mean values \pm standard deviation. All statistical analyses were performed using Minitab Statistical Software version 16.0 (Minitab Inc., State College, PA, USA). The results were analyzed by one-way analysis of variance (ANOVA) and the significant means separated by Tukey method $(\mathrm{P}<0.05)$.

\section{RESULTS}

\section{Physiochemical properties of roselle-fruit blends}

Table 1 shows the changes in total soluble solids (TSS), $\mathrm{pH}$, titratable acidity (TA) and reducing sugar (RS) in roselle-fruit blends. $\mathrm{pH}$ for all roselle-fruit juice blends and TSS for roselle-mango blends decreased significantly $(\mathrm{P}<0.05)$ with decreasing concentration of roselle extract in all the blends while RS for all roselle-fruit juice blends increased significantly $(\mathrm{P}<0.05)$ with increased concentration of roselle extract in all the roselle-fruit blends.

Total soluble solids (TSS) for roselle extract, mango, papaya and guava were 5.70, 14.03, 7.88 and $5.88{ }^{\circ}$ Brix. Total soluble solids TSS for roselle-mango, rosellepapaya and roselle-guava blends ranged from $10.62-5.6^{\circ}$ Brix (Table 1). The reducing sugars (RS) value for roselle extract, mango, papaya and guava were 2.42, 5.87, 5.73 and $5.55 \mathrm{mg} / 100 \mathrm{~g}$, for roselle-mango roselle-papaya and roselle-guava blends ranged from 5.55-2.95 mg/100g (Table 1). 


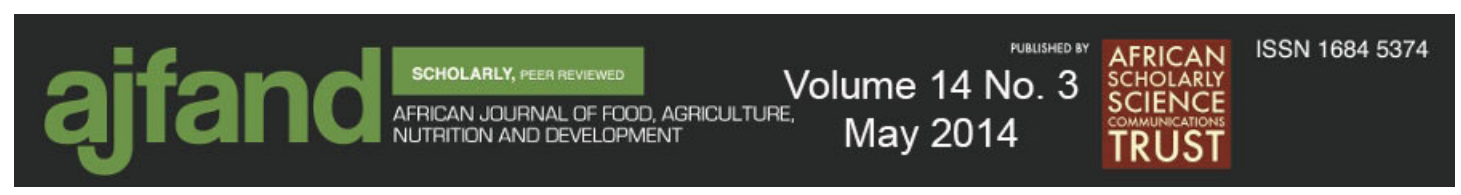

The $\mathrm{pH}$ values for roselle extract, mango, papaya and guava was 2.26, 3.37, 4.48 and 3.72. $\mathrm{pH}$ for roselle-mango, roselle-papaya and roselle-guava blends were 3.32-2.35 (Table 1). The titratable acidity (TA) for roselle extract, mango, papaya and guava were $1.92,0.32,0.20$ and 0.57 . TA for roselle-mango, roselle-papaya and roselleguava blends ranged from 1.92-0.96\% (Table 1).

\section{Mineral composition of roselle-fruit blends}

The composition of minerals in roselle-fruit blends is showed in Table 2. From the results as amount of roselle extract decrease in all the roselle fruit blends, the quantity of minerals (except sodium) also decreased significantly $(\mathrm{P}<0.05)$. Calcium content (Ca) for roselle extract, mango, papaya and guava was 880.8, 4.1, 16.9 and 18.5. Calcium for roselle-fruit juice blends ranged from 555.3-23.4 mg/100g while magnesium (Mg) content for roselle extract, mango, papaya and guava was 316.6, 4.0, 6.6 and 22.4. Magnesium for roselle-fruit juices blends ranged from 213.8-11.5 $\mathrm{mg} / 100 \mathrm{~g}$ (Table 2).

Phosphorus (P) for roselle extract, mango, papaya and guava was 40.2, 5.0, 36.5 and 36.5. Phosphorus for roselle-fruit juices blends ranged from 39.81-37.8 mg/100g DM and iron (Fe) content for roselle extract, mango, papaya and guava was 37.8, 0.1, 3.2 and 0.4. Iron content for roselle-fruit juices blends ranged from 29.5-1.4 mg/100g (Table 2). Sodium (Na) content for roselle extract, mango, papaya and guava was 6.6, 1.0, 2.2 and 2.2. Sodium content for roselle-fruit juices blends ranged from 5.6-1.0 $\mathrm{mg} / 100 \mathrm{~g}$ while zinc content $(\mathrm{Zn})$ for roselle extract, mango, papaya and guava was 6.4, 0.1, 0.2 and 0.2. Zinc content for roselle-fruit juices blends ranged from 5.7$0.6 \mathrm{mg} / 100 \mathrm{~g}$ (Table 2).

\section{Antioxidant properties of roselle-fruit blends}

Vitamin C content for roselle extract, mango, papaya and guava were 37.4, 62.2, 73.5 and $92.2 \mathrm{mg} / 100 \mathrm{~g}$. Roselle-fruit juices blends were between 40.0-61.2 mg/100g (Table 3). Total monomeric anthocyanins (TMA) values for roselle extract, mango, papaya and guava were 555.3, 48.0, 46.8 and $62.8 \mathrm{mg} / 100 \mathrm{~g}$. Total monomeric anthocyanins (TMA) for roselle- fruit juice blends were between 493.5-118.2 $\mathrm{mg} / 100 \mathrm{~g}$ (Table 3). Total phenol content (TPC) for roselle extract, mango, papaya and guava were 54.6, 10.9, 6.8 and $27.3 \mathrm{mg} / 100 \mathrm{~g}$. Roselle-fruit juices blends were between 53.7-10.8 GAE mg/100g (Table 3). Ferric reducing ability of plasma (FRAP) for roselle extract, mango, papaya and guava were 1.87, 1.28, 1.37 and $1.42 \mathrm{mMol} / \mathrm{L}$. Roselle- fruit juice blends was $1.80-1.37 \mathrm{mMol} / \mathrm{L}$ (Table 3). The results showed that as the concentration of roselle in all the blends increased, the quantity of TMA and TPC in the blends also increased significantly $(\mathrm{P}<0.05)$ while quantity of vitamin $\mathrm{C}$ decreased.

\section{Colour}

The lightness $\left(\mathrm{L}^{*}\right)$ and the yellowness $\left(\mathrm{b}^{*}\right)$ values for all blends increased while the redness $\left(\mathrm{a}^{*}\right)$ values decreased significantly $(\mathrm{P}<0.05)$ with decreased concentration of roselle extract in the blends (Table 4). The lightness ( $\mathrm{L}^{*}$ ) values for roselle extract, mango, papaya and guava was 14.3, 42.4, 41.4 and 21.3. Lightness for roselle-fruit 
juices blends ranged from 15.8 to 18.3 while the redness $\left(\mathrm{a}^{*}\right)$ value for roselle extract, mango, papaya and guava was 20.6, 6.6, 14.5 and 15.4. Redness value for roselle-fruit juices blends ranged from 20.0 to 15.4 (Table 4). The yellowness (b*) value for roselle extract, mango, papaya and guava was 3.9, 43.9, 48.0 and 8.3. The $b^{*}$ value for roselle-fruit juices blends ranged from 8.5 to 4.5 (Table 4).

\section{DISCUSSION}

\section{Physiochemical properties of roselle-fruit blends}

Roselle extract is known to be highly acidic with low sugar content [4, 5, 22]. The increase in TSS and RS is due to high sugar content in fruit juices and roselle-mango blends showed highest proportion of sugars among the three fruits used in the blending. The low $\mathrm{pH}$ of roselle extract was increased by addition of tropical fruit juices in roselle juice. The reduction of acidity for roselle-fruit blends can be good to people with stomach problems (ulcers) and also increase the shelf life of blends (3).

\section{Mineral composition of roselle-fruit blends}

Macro-minerals are needed in large amounts and play major structural roles (such as calcium and phosphorus) and function as electrolytes (such as sodium and potassium). Micro-minerals (trace minerals), often serve as catalysts in enzyme reactions and are only needed in small amounts [3]. Roselle extract is known to be good source of calcium, magnesium, iron and phosphorus [3, 23]. The decrease in mineral composition with decreased concentration on roselle extract in roselle-apple blends was also reported by Fasoyiro et al. [22]. The daily recommended Fe requirements for humans are 10-15 mg for children, $18 \mathrm{mg}$ for women and $12 \mathrm{mg}$ for men [24]. The concentrations of $\mathrm{Fe}$ in $100 \% \mathrm{R}$ to $60 \% \mathrm{R}$ for all the roselle fruit blends provide more than $100 \%$ DRI. The roselle-fruit blends can be good source of Fe and can therefore alleviate of iron deficiency.

The vitamin C content of mango, papaya and guava juices were higher than the value of recorded for roselle extract alone. Addition of fruit juice has improved the vitamin C content of the blends. However, all the roselle blends were good source of Vitamin C. The increased vitamin C content with decreased content of sobo (roselle) was also observed in sobo-orange and sobo-pineapple mixture [25].

Anthocyanins are plant pigments responsible for the red, blue, and purple colours of various flowers and plants [21]. The determination of anthocyanins composition in food as well as processed food has been of considerable interest to establish their role as antioxidants in determining their potential health benefits. Roselle extract is a very good source of anthocyanins [5, 6, 21]. Daily intake of anthocyanins is estimated to be $82 \mathrm{mg}$ and $12.5 \mathrm{mg}$ per day per person in Finland and United States [26]. The amount of anthocyanin in the roselle-fruit blends ( $80 \% \mathrm{R}$ to $20 \% \mathrm{R})$ is equivalent to 6 1.4 times, 39 - 9 times) the recommended daily intake for Finland and USA, respectively. 


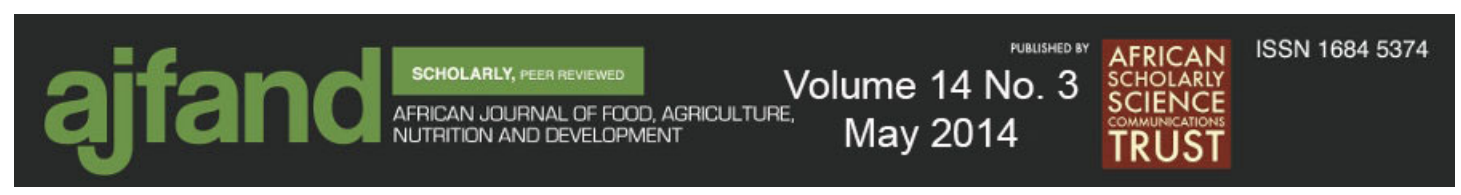

Phenolic compounds including anthocyanins, flavonoids, and phenolic acids are known to be responsible for antioxidant activities in fruits and fruits with higher phenolic contents generally show stronger antioxidant activities [28]. The concept of antioxidant activities which describes the ability of different food antioxidants in scavenging preformed free radicals is a tool for investigating the health effects of antioxidant-rich foods. The reduction in FRAP was due to decreased amount of anthocyanins and total phenol in the blend as concentration of roselle extract is reduced in the blends.

\section{Colour}

Colour is the most important quality attribute having influence on consumer acceptability of food as it gives the first impression of food quality [3]. The red colour is due to presence of anthocyanins $[3,6]$ in the roselle blends. From the results, as the concentration of roselle extract decreased the redness decrease. The yellow colour is due to the presence of carotenoids in (mango, guava and papaya) so as the concentration of fruit juices increased in the blends the yellowness also increased.

\section{CONCLUSIONS}

The combinations of roselle extract with fruit juices (mango, papaya and guava) are rich in essential minerals and vitamin $C$ and these blends could replace the existing commercially available non-alcoholic beverages in stores and supermarkets.

Antioxidants act as free radical scavengers, inhibit lipid peroxidation and other free radical mediated process, therefore consumption of roselle-fruit juices with high anthocyanin (493.5-118.2) $\mathrm{mg} / \mathrm{L}$ will protect human body from several diseases attributed to the reactions of free radicals.

The formulated roselle fruit (mango, papaya and guava) is an ideal low cost blended beverage as the addition of mango, papaya, guava in the roselle extract could bring down cost of production as these tropical fruit are sold at a throw-away price during their seasons and reduce seasonal losses of these fruits.

\section{ACKNOWLEDGMENT}

This research was funded by the Norwegian Programme for Development, Research and Education (NUFU, project 2008/10265) through Norwegian University of Life Sciences, Mekelle University, Hawassa University and Sokoine University of Agriculture. 


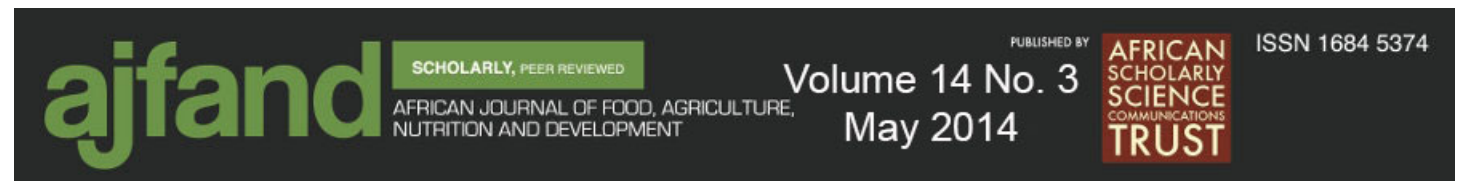

Table 1: Physiochemical properties of roselle-fruit blends

\begin{tabular}{|c|c|c|c|c|c|}
\hline \multirow[t]{2}{*}{ Fruits } & \multirow[t]{2}{*}{ Blends } & TSS & \multirow[t]{2}{*}{ PH } & TA & $\mathrm{RS}$ \\
\hline & & ${ }^{\circ}$ Brix & & $\%$ malic acid & $\mathrm{mg} / 100 \mathrm{~g}$ \\
\hline \multirow[t]{6}{*}{ Mango } & OR & $14.03^{\mathrm{a}} \pm 0.50$ & $3.37^{\mathrm{a}} \pm 0.12$ & $0.32^{\mathrm{c}} \pm 0.43$ & $5.87^{\mathrm{a}} \pm 0.05$ \\
\hline & $20 \mathrm{R}$ & $10.62^{\mathrm{a}} \pm 0.49$ & $2.76^{b} \pm 0.14$ & $1.44^{\mathrm{b}} \pm 0.00$ & $5.55^{\mathrm{b}} \pm 0.00$ \\
\hline & $40 \mathrm{R}$ & $9.92^{\mathrm{a}} \pm 0.19$ & $2.65^{b} \pm 0.01$ & $1.92^{\mathrm{b}} \pm 0.43$ & $5.06^{\mathrm{c}} \pm 0.00$ \\
\hline & $60 \mathrm{R}$ & $7.48^{\mathrm{b}} \pm 0.63$ & $2.40^{\mathrm{c}} \pm 0.06$ & $3.12^{\mathrm{a}} \pm 0.40$ & $4.51^{\mathrm{d}} \pm 0.00$ \\
\hline & $80 \mathrm{R}$ & $6.90^{\mathrm{b}} \pm 0.20$ & $2.35^{c} \pm 0.01$ & $1.40^{\mathrm{b}} \pm 0.00$ & $3.48^{\mathrm{e}} \pm 0.0^{0}$ \\
\hline & $100 \mathrm{R}$ & $5.70^{\mathrm{c}} \pm 0.10$ & $2.26^{\mathrm{d}} \pm 0.01$ & $1.92^{\mathrm{b}} \pm 0.00$ & $2.42^{f} \pm 0.00$ \\
\hline \multirow[t]{6}{*}{ Papaya } & OR & $7.88^{\mathrm{a}} \pm 0.45$ & $4.48^{\mathrm{a}} \pm 0.03$ & $0.20^{\mathrm{d}} \pm 0.00$ & $5.73^{\mathrm{a}} \pm 0.02$ \\
\hline & $20 \mathrm{R}$ & $6.90^{\mathrm{b}} \pm 0,35$ & $3.32^{b} \pm 0.01$ & $1.28^{\mathrm{c}} \pm 0.25$ & $5.18^{\mathrm{b}} \pm 0.00$ \\
\hline & $40 \mathrm{R}$ & $7.60^{\mathrm{a}} \pm 0.15$ & $2.94^{c} \pm 0.01$ & $1.36^{\mathrm{c}} \pm 0.2$ & $4.87^{c} \pm 0.00$ \\
\hline & $60 \mathrm{R}$ & $7.80^{\mathrm{a}} \pm 0.00$ & $2.69^{d} \pm 0.01$ & $1.60^{\mathrm{b}} \pm 0.47$ & $3.45^{\mathrm{d}} \pm 0.02$ \\
\hline & $80 \mathrm{R}$ & $6.75^{b} \pm 0.08$ & $2.54^{\mathrm{e}} \pm 0.00$ & $2.00^{\mathrm{a}} \pm 0.47$ & $2.95^{\mathrm{e}} \pm 0.01$ \\
\hline & $100 \mathrm{R}$ & $5.70^{c} \pm 0.37$ & $2.26^{\mathrm{f}} \pm 0.02$ & $1.92^{\mathrm{a}} \pm 0.00$ & $2.42^{\mathrm{f}} \pm 0.00$ \\
\hline \multirow[t]{6}{*}{ Guava } & OR & $5.88^{\mathrm{c}} \pm 0.10$ & $3.72^{\mathrm{a}} \pm 0.01$ & $0.57^{\mathrm{d}} \pm 0.66$ & $5.55^{\mathrm{a}} \pm .01$ \\
\hline & $20 \mathrm{R}$ & $5.60^{\mathrm{c}} \pm 0.10$ & $3.13^{b} \pm 0.01$ & $1.92^{\mathrm{a}} \pm 0.00$ & $4.35^{b} \pm .01$ \\
\hline & $40 \mathrm{R}$ & $5.87^{c} \pm 0.00$ & $2.53^{c} \pm 0.03$ & $1.36^{c} \pm 0.20$ & $4.10^{\mathrm{c}} \pm .02$ \\
\hline & $60 \mathrm{R}$ & $6.30^{\mathrm{b}} \pm 0.00$ & $2.83^{d} \pm 0.01$ & $0.9^{\mathrm{d}} 6 \pm 0.0$ & $3.88^{d} \pm .00$ \\
\hline & $80 \mathrm{R}$ & $6.70^{\mathrm{a}} \pm 0.00$ & $2.41^{\mathrm{e}} \pm 0.01$ & $1.68^{b} \pm 0.26$ & $3.23^{\mathrm{e}} \pm .00$ \\
\hline & $100 \mathrm{R}$ & $5.70^{\mathrm{c}} \pm 0.00$ & $2.26^{\mathrm{f}} \pm 0.00$ & $1.92^{\mathrm{a}} \pm 0.42$ & $2.42^{\mathrm{f}} \pm .01$ \\
\hline
\end{tabular}

Data in columns for each fruit with different superscript are significantly different using Tukey's pair-wise comparison test $(\mathrm{p}<0.05)$. 100R $=100 \%$ Roselle; $80 \mathrm{R}=80 \%$ Roselle; 60R=60\% Roselle; 40R=40\% Roselle; 20R=20\% Roselle; 0R=100\% Mango or $100 \%$ Papaya or $100 \%$ Guava. 


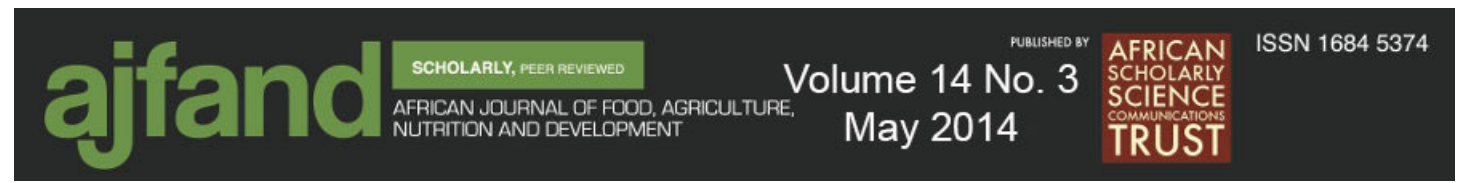

Table 2: Minerals composition of roselle-fruit blends

\begin{tabular}{|c|c|c|c|c|c|c|c|}
\hline \multirow[t]{2}{*}{ Fruit juice } & Blend & Calcium & Magnesium & Phosphorus & Iron & Sodium & Zinc \\
\hline & \multicolumn{7}{|c|}{ mg/100 g DW } \\
\hline \multirow[t]{6}{*}{ Mango } & OR & $4.1^{\mathrm{f}} \pm 0.00$ & $4.0^{f} \pm 0.00$ & $5.0^{f} \pm 0.00$ & $0.1^{f} \pm 0.00$ & $1.0^{\mathrm{f}} \pm .00$ & $0.1^{\mathrm{f}} \pm .00$ \\
\hline & $20 \mathrm{R}$ & $37.3^{\mathrm{e}} \pm 0.20$ & $11.5^{\mathrm{e}} \pm 0.10$ & $9.0^{\mathrm{e}} \pm 0.00$ & $1.4^{\mathrm{e}} \pm 0.00$ & $6.6^{\mathrm{e}} \pm .00$ & $0.6^{\mathrm{e}} \pm .00$ \\
\hline & $40 \mathrm{R}$ & $97.5^{d} \pm 0.00$ & $24.9^{\mathrm{d}} \pm 0.10$ & $14.4^{\mathrm{d}} \pm 0.00$ & $6.4^{\mathrm{d}} \pm 0.00$ & $11.8^{\mathrm{d}} \pm .01$ & $1.1^{\mathrm{d}} \pm .01$ \\
\hline & $60 \mathrm{R}$ & $255.4^{\mathrm{c}} \pm 3.70$ & $100.4^{\mathrm{c}} \pm 0.40$ & $22.5^{\mathrm{c}} \pm 0.00$ & $15.7^{\mathrm{c}} \pm 0.00$ & $13.7^{\mathrm{c}} \pm .00$ & $4.9^{\mathrm{c}} \pm .00$ \\
\hline & $80 \mathrm{R}$ & $555.3^{\mathrm{b}} \pm 2.00$ & $213.8^{\mathrm{b}} \pm 0.80$ & $30.8^{\mathrm{b}} \pm 0.00$ & $28.2^{\mathrm{b}} \pm 0.00$ & $15.5^{\mathrm{b}} \pm .02$ & $5.6^{\mathrm{b}} \pm .02$ \\
\hline & $100 \mathrm{R}$ & $880.8^{\mathrm{a}} \pm 0.01$ & $316.6^{\mathrm{a}} \pm 0.30$ & $40.0^{\mathrm{a}} \pm 0.04$ & $37.8^{\mathrm{a}} \pm 0.00$ & $6.6^{\mathrm{a}} \pm 0.00$ & $6.4^{\mathrm{a}} \pm 0.00$ \\
\hline \multirow[t]{6}{*}{ Papaya } & OR & $16.9^{\mathrm{f}} \pm 0.02$ & $6.6^{\mathrm{f}} \pm 0.31$ & $36.5^{f} \pm 0.02$ & $3.21^{f} \pm 0.03$ & $2.2^{\mathrm{a}} \pm 0.01$ & $2.22^{\mathrm{a}} \pm 0.01$ \\
\hline & $20 \mathrm{R}$ & $36.2^{\mathrm{e}} \pm 0.02$ & $33.9^{\mathrm{e}} \pm 0.00$ & $36.8^{\mathrm{e}} \pm 0.31$ & $5.3^{\mathrm{e}} \pm 0.00$ & $2.3^{\mathrm{e}} \pm 0.12$ & $2.31^{\mathrm{e}} \pm 0.12$ \\
\hline & $40 \mathrm{R}$ & $85.4^{\mathrm{d}} \pm 0.18$ & $88.8^{\mathrm{d}} \pm 0.02$ & $38.8^{d} \pm 0.05$ & $8.6^{\mathrm{d}} \pm 0.01$ & $2.9^{\mathrm{d}} \pm 0.00$ & $2.94^{\mathrm{d}} \pm 0.00$ \\
\hline & $60 \mathrm{R}$ & $148.6^{\mathrm{c}} \pm 0.23$ & $124.4^{\mathrm{C}} \pm 0.07$ & $37.5^{c} \pm 0.00$ & $19.2^{\mathrm{C}} \pm 0.00$ & 3. $7^{c} \pm 0.01$ & $3.67^{\mathrm{c}} \pm 0.01$ \\
\hline & $80 \mathrm{R}$ & $459.5^{b} \pm 0.25$ & $190.4^{\mathrm{b}} \pm 0.04$ & $39.3^{b} \pm 0.03$ & $28.4^{\mathrm{b}} \pm 0.00$ & $5.6^{\mathrm{b}} \pm 0.01$ & $5.6^{\mathrm{b}} \pm 0.01$ \\
\hline & $100 \mathrm{R}$ & $880.8^{\mathrm{a}} \pm 0.01$ & $316.6^{\mathrm{a}} \pm 0.30$ & $40.0^{a} \pm 0.04$ & $37.8^{\mathrm{a}} \pm 0.00$ & $6.6^{\mathrm{a}} \pm 0.00$ & $6.4^{\mathrm{a}} \pm 0.00$ \\
\hline \multirow[t]{6}{*}{ Guava } & OR & $18.5^{\mathrm{f}} \pm 0.16$ & $22.4^{\mathrm{f}} \pm 0.23$ & $36.5^{f} \pm 0.01$ & $0.4^{\mathrm{f}} \pm 0.01$ & $2.2^{\mathrm{f}} \pm 0.01$ & $0.2^{\mathrm{f}} \pm 0.01$ \\
\hline & 20R & $23.4^{\mathrm{e}} \pm 0.16$ & $54.6^{\mathrm{e}} \pm 0.22$ & $37.8^{\mathrm{e}} \pm 0.01$ & $2.7^{\mathrm{e}} \pm 0.01$ & $3.5^{\mathrm{e}} \pm 0.12$ & $0.7^{\mathrm{e}} \pm 0.12$ \\
\hline & $40 \mathrm{R}$ & $58.6^{\mathrm{d}} \pm 0.07$ & $64.5^{\mathrm{d}} \pm 0.35$ & $38.3^{d} \pm 0.00$ & $6.0^{\mathrm{d}} \pm 0.01$ & $4.8^{\mathrm{d}} \pm 0.00$ & $1.4^{\mathrm{d}} \pm 0.00$ \\
\hline & $60 \mathrm{R}$ & $120.5^{c} \pm 0.43$ & $78.7^{c} \pm 0.16$ & $39.3^{\mathrm{c}} \pm 0.00$ & $14.1^{\mathrm{c}} \pm 0.01$ & $5.5^{c} \pm 0.01$ & $2.6^{c} \pm 0.01$ \\
\hline & $80 \mathrm{R}$ & $420.6^{b} \pm 0.28$ & $116.6^{b} \pm 0.30$ & $39.8^{\mathrm{b}} \pm 0.00$ & $29.5^{b} \pm 0.01$ & $6.1^{b} \pm 0.01$ & $5.6^{\mathrm{b}} \pm 0.01$ \\
\hline & $100 \mathrm{R}$ & $880.8^{a} \pm 0.01$ & $316.6^{\mathrm{a}} \pm 0.27$ & $40.2^{a} \pm 0.04$ & $37.8^{\mathrm{a}} \pm 0.00$ & $6.6^{\mathrm{a}} \pm 0.00$ & $6.4^{\mathrm{a}} \pm 0.00$ \\
\hline DRI(mg/day) & & 1000 & $320 ; 420$ & 700 & $18 ; 8$ & 1500 & $8 ; 11$ \\
\hline
\end{tabular}

Data in columns for each fruit with different superscript are significantly different using Tukey's pair-wise comparison test $(\mathrm{p}<0.05)$. Dietary reference intakes (DRI) are established by the US Food and Nutrition Board of the (IMO, 2002, 2004) National Academy of Sciences. Values given are for adult females and males, ages 19-50 years. 


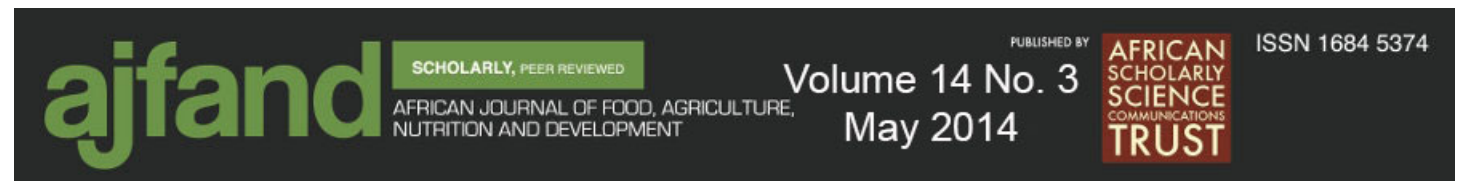

Table 3: Antioxidant properties of roselle-fruit blends

\begin{tabular}{|c|c|c|c|c|c|}
\hline Fruits & Blends & $\begin{array}{c}\text { Vitamin C } \\
\text { mg/100g }\end{array}$ & $\begin{array}{r}\text { TMA } \\
\mathrm{mg} / 100 \mathrm{~g}\end{array}$ & $\begin{array}{r}\text { TPC } \\
\mathrm{mg} / 100 \mathrm{~g}\end{array}$ & $\begin{array}{r}\text { FRAP } \\
\mathrm{mMol} / \mathrm{L}\end{array}$ \\
\hline \multirow[t]{6}{*}{ Mango } & OR & $62.2^{\mathrm{a}} \pm 0.00$ & $48.0^{f} \pm 0.75$ & $10.9^{\mathrm{e}} \pm 5.22$ & $1.28^{\mathrm{f}} \pm 0.00$ \\
\hline & $20 \mathrm{R}$ & 58. $5^{\mathrm{b}} \pm 0.00$ & $134.7^{\mathrm{e}} \pm 1.50$ & $21.3^{\mathrm{d}} \pm 0.01$ & $1.45^{\mathrm{e}} \pm 0.00$ \\
\hline & $40 \mathrm{R}$ & $53.0^{c} \pm 0.00$ & $282.6^{\mathrm{d}} \pm 1.81$ & $28.8^{c} \pm 0.03$ & $1.58^{\mathrm{d}} \pm 0.00$ \\
\hline & $60 \mathrm{R}$ & $44.4^{\mathrm{d}} \pm 0.00$ & $335.2^{\mathrm{c}} \pm 1.54$ & $37.9^{c} \pm 0.03$ & $1.66^{\mathrm{c}} \pm 0.00$ \\
\hline & $80 \mathrm{R}$ & $40.0^{\mathrm{e}} \pm 0.00$ & $493.5^{b} \pm 5.15$ & $53.7^{b} \pm 0.02$ & $1.80^{\mathrm{b}} \pm 0.00$ \\
\hline & 100R & $37.4^{\mathrm{f}} \pm 0.00$ & $555.3^{\mathrm{a}} \pm 2.03$ & $54.6^{\mathrm{a}} \pm 0.80$ & $1.87^{\mathrm{a}} \pm 0.01$ \\
\hline \multirow[t]{6}{*}{ Papaya } & OR & $73.5^{\mathrm{a}} \pm 0.00$ & $46.8^{\mathrm{f}} \pm 1.00$ & $6.8^{\mathrm{f}} \pm 0.06$ & $1.28^{\mathrm{f}} \pm 0.02$ \\
\hline & $20 \mathrm{R}$ & $61.2^{\mathrm{b}} \pm 0.00$ & $146.0^{\mathrm{e}} \pm 6.20$ & $10.8^{\mathrm{e}} \pm 0.00$ & $1.37^{\mathrm{e}} \pm 0.00$ \\
\hline & $40 \mathrm{R}$ & $54.3^{\mathrm{c}} \pm 0.00$ & $290.2^{d} \pm 8.83$ & $19.8^{\mathrm{d}} \pm 0.01$ & $1.59^{\mathrm{d}} \pm 0.00$ \\
\hline & $60 \mathrm{R}$ & $47.9^{\mathrm{d}} \pm 0.00$ & $339.2^{\mathrm{c}} \pm 3.31$ & $39.5^{c} \pm 0.01$ & $1.63^{\mathrm{c}} \pm 0.00$ \\
\hline & $80 \mathrm{R}$ & $41.4^{\mathrm{e}} \pm 0.00$ & $454.6^{\mathrm{b}} \pm 3.03$ & $51.3^{\mathrm{b}} \pm 0.00$ & $1.76^{\mathrm{b}} \pm 0.00$ \\
\hline & $100 \mathrm{R}$ & $37.45^{\mathrm{f}} \pm 0.00$ & $555.3^{\mathrm{a}} \pm 0.30$ & $54.6^{\mathrm{a}} \pm 0.80$ & $1.87^{\mathrm{a}} \pm 0.01$ \\
\hline \multirow[t]{6}{*}{ Guava } & OR & $92.2^{\mathrm{a}} \pm 0.01$ & $62.8^{\mathrm{f}} \pm 1.38$ & $27.3^{\mathrm{f}} \pm 0.00$ & $1.42^{\mathrm{f}} \pm 0.03$ \\
\hline & $20 \mathrm{R}$ & $44.3^{\mathrm{e}} \pm 0.00$ & $118.2^{\mathrm{e}} \pm 0.95$ & $47.3^{\mathrm{b}} \pm 0.00$ & $1.75^{\mathrm{b}} \pm 0.00$ \\
\hline & $40 \mathrm{R}$ & $57.3^{d} \pm 0.00$ & $167.8^{\mathrm{d}} \pm 2.51$ & $39.9^{c} \pm 0.00$ & $1.62^{\mathrm{c}} \pm 0.00$ \\
\hline & $60 \mathrm{R}$ & $74.7^{\mathrm{c}} \pm 0.00$ & $218.9^{\mathrm{c}} \pm 2.15$ & $32.0^{\mathrm{d}} \pm 0.01$ & $1.56^{\mathrm{d}} \pm 0.00$ \\
\hline & $80 \mathrm{R}$ & $86.5^{b} \pm 0.00$ & $373.2^{b} \pm 1.38$ & $29.8^{\mathrm{e}} \pm 0.01$ & $1.49^{\mathrm{e}} \pm 0.04$ \\
\hline & $100 \mathrm{R}$ & $37.4^{\mathrm{f}} \pm 0.00$ & $555.3^{\mathrm{a}} \pm 0.5$ & $54.6^{\mathrm{a}} \pm 0.28$ & $1.87^{\mathrm{a}} \pm 0.01$ \\
\hline
\end{tabular}

Data in columns for each fruit with different superscript are significantly different using Tukey's pair-wise comparison test $(\mathrm{p}<0.05)$. 


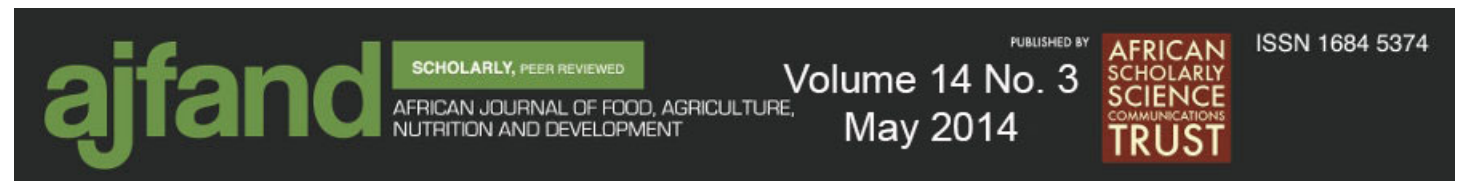

Table 4: The colour measurements values $\left(L^{*} a^{*} b^{*}\right)$ for roselle-fruit blends

\begin{tabular}{|c|c|c|c|c|c|c|c|c|c|}
\hline \multirow[t]{2}{*}{ Blends } & \multicolumn{2}{|l|}{ Mango } & \multicolumn{3}{|c|}{ Papaya } & \multicolumn{3}{|c|}{ Guava } & \multirow[b]{2}{*}{$b^{*}$} \\
\hline & $\mathrm{L}^{*}$ & $a^{*}$ & $b^{*}$ & $\mathrm{~L}^{*}$ & $a^{*}$ & $b^{*}$ & $\mathrm{~L}^{*}$ & $a^{*}$ & \\
\hline OR & $\begin{array}{r}42.4 \mathrm{a} \\
\pm 0.7\end{array}$ & $\begin{array}{r}06.6 \mathrm{e} \\
\pm 0.3\end{array}$ & $43.9 \mathrm{a} \pm 0.6$ & $41.4 \mathrm{a} \pm 0.2$ & $14.5 \mathrm{f} \pm 0.1$ & $\begin{array}{r}48.0 \mathrm{a} \\
\pm 0.3\end{array}$ & $21.3 \mathrm{a} \pm 0.1$ & $15.4 \mathrm{e} \pm 0.4$ & $\begin{array}{l}8.3 \mathrm{a} \\
\pm 0.1\end{array}$ \\
\hline $20 \mathrm{R}$ & $18.6 b \pm 0.4$ & $\begin{array}{r}16.4 \mathrm{~d} \\
\pm 0.2\end{array}$ & $8.5 \mathrm{~b} \pm 0.2$ & $18.3 \mathrm{~b} \pm 0.1$ & $15.4 \mathrm{e} \pm 0.3$ & $7.4 \mathrm{~b} \pm 0.1$ & $19.6 \mathrm{~b} \pm 0.4$ & $16.5 \mathrm{~d} \pm 0.2$ & $\begin{array}{l}7.3 \mathrm{~b} \\
\pm 0.4\end{array}$ \\
\hline $40 \mathrm{R}$ & $17.6 \mathrm{c} \pm 0.3$ & $\begin{array}{r}18.1 \mathrm{c} \\
\pm 0.7\end{array}$ & $7.7 c \pm 0.5$ & $17.8 \mathrm{c} \pm 0.4$ & $16.2 \mathrm{~d} \pm 0.4$ & $6.4 \mathrm{~d} \pm 0.1$ & $16.3 \mathrm{c} \pm 0.0$ & $17.2 \mathrm{c} \pm 0.4$ & $\begin{array}{l}6.4 \mathrm{c} \\
\pm 0.0\end{array}$ \\
\hline $60 \mathrm{R}$ & $16.1 \mathrm{~d} \pm 0.2$ & $\begin{array}{r}19.2 \mathrm{a} \\
\pm 0.4\end{array}$ & $56 \mathrm{~d} \pm 0.2$ & $16.6 \mathrm{~d} \pm 0.0$ & $18.8 \mathrm{c} \pm 0.1$ & $6.0 \mathrm{c} \pm 0.0$ & $15.8 \mathrm{~d} \pm 0.1$ & $17.6 \mathrm{c} \pm 0.0$ & $\begin{array}{l}5.3 \mathrm{~d} \\
\pm 0.0\end{array}$ \\
\hline $80 \mathrm{R}$ & $\begin{array}{r}14.7 \mathrm{e} \\
\pm 0.1\end{array}$ & $\begin{array}{r}20.0 \mathrm{a} \\
\pm 0.5\end{array}$ & 4.7e \pm 0.6 & $15.8 \mathrm{e} \pm 0.0$ & $19.9 \mathrm{~b} \pm 0.1$ & $5.7 \mathrm{c} \pm 1.8$ & $15.1 \mathrm{e} \pm 0.0$ & $19.5 \mathrm{~b} \pm 0.1$ & $\begin{array}{l}4.5 \mathrm{e} \\
\pm 0.2\end{array}$ \\
\hline $100 \mathrm{R}$ & $\begin{array}{r}14.3 \mathrm{e} \\
\pm 0.0\end{array}$ & $\begin{array}{r}20.6 \mathrm{a} \\
\pm 0.0\end{array}$ & $3.9 f \pm 0.0$ & $14.3 \mathrm{f} \pm 0.0$ & $20.6 \mathrm{a} \pm 0.0$ & $3.9 \mathrm{~d} \pm 0.0$ & $14.3 \mathrm{f} \pm 0.0$ & $20.6 \mathrm{a} \pm 0.0$ & $\begin{array}{c}3.9 \mathrm{f} \\
\pm 0.0\end{array}$ \\
\hline
\end{tabular}

Data in columns for each fruit with different superscript are significantly different using Tukey's pair-wise comparison test $(\mathrm{p}<0.05)$. 


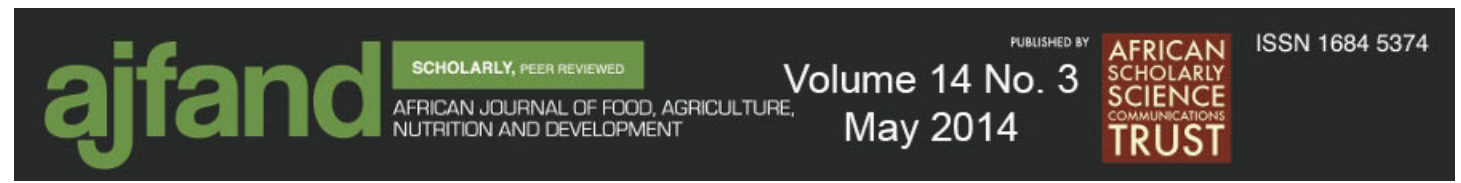

\section{REFERENCES}

1. Wong PK, Yusof S, Ghazali HM and Y Bin Che Man Optimization of hot water extraction of roselle juice using response surface methodology: a comparative study with other extraction methods. Journal of the Science of Food and Agriculture 2003; 83 (12) 1273-1278.

2. Obadina AO and OB Oyewole Assessment of the antimicrobial potential of roselle juice (zobo) from different varieties of roselle calyx. J. Food Process. Preservation 2007; 31: 607-617.

3. Abou-Arab AA, Abu-Salem FM and EA Abou-Arab Physico- chemical properties of natural pigments (anthocyanin) extracted from Roselle calyces (Hibiscus subdariffa). Journal of American Science 2001; 7 (7): 445-456.

4. Sagayo-Ayerdi SG, Arranz S, Serrano J and I Goni Dietary fiber content and associated antioxidant compounds in roselle flower (Hibiscus sabdariffa L.) beverage. J. Agric. Food Chem. 2007; 55: 7886-7890.

5. Tsai JP, McIntosh J, Pearce P, Camden B and BR Jordan Anthocyanin and antioxidant capacity in Roselle (Hibiscus Sabdariffa L.) extract. Food Research International 2002; 35: 351-356.

6. Tsai PJ and HP Huang Effect of polymerization on the antioxidant capacity of anthocyanins in Roselle. Food Research International 2004; 37: 313-318.

7. Duangmal K, Saicheua $\mathbf{B}$ and S Sueeprasan Colour evaluation of freezedried roselle extract as a natural food colorant in a model system of a drink. LWT - Food Science and Technology 2008; 41: 1437-1445.

8. Ashaye OA, Babalola SO, Babalola AO, Aina JO and S Fasoyiro Chemical and organoleptic characterization of pawpaw and guava leathers. World Journal of Agricultural Sciences 2005; 1 (1): 50-51.

9. Jawaheer B, Goburdhun D and A Ruggoo Effect of processing and storage of guava into jam and juice on the Ascorbic acid content. Plant Foods for Human Nutrition 2003; 58:1-12.

10. Thaipong $\mathbf{K}$, Boonprakob $\mathbf{U}$, Crosby $\mathbf{K}$, Cisneros-Zevallos $\mathbf{L}$ and $\mathbf{D H}$ Byrne Comparison of ABTS, DPPH, FRAP, and ORAC assays for estimating antioxidant activity from guava fruit extracts. Journal of Food Composition and Analysis 2006; 19 (6-7): 669-675.

11. Parker, TL Esgro, ST Miller, SA Myers LE, Meister RA, Toshkov SA and NJ Engeseth Development of an optimised papaya pulp nectar using a combination of irradiation and mild heat. Food Chemistry 2010; 118 (3): 861869. 


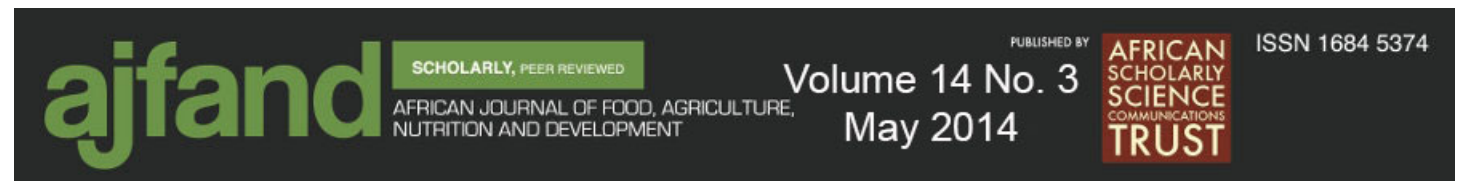

12. Chowdhury MGF, Islam MN, Islam MS, Tariqul Islam AFM and MS Hossain Preparation and Shelf-Life of Mixed Juice Based on Wood Apple and Papaya. J.Soil.Nature. 2008; 2 (3):50-60.

13. Akhter S, Masood S, Jadoon SH, Ahmad I and S Ullah Quality evaluation of different brands of Tetra Pak mango juices available in market. Pak. J. Food Sci. 22: 2 96-100.

14. Gerbaud P Mango. Fruit Trop. 2008; 153: 10-35.

15. Chumsri P, Sirichote A and A Itharat Studies on the optimum conditions for the extraction and concentration of roselle (Hibiscus sabdariffa Linn.) extract. Songklanakarin J. Sci. Technol. 2008; 30 (1): 133-139.

16. AOAC. Official methods of analysis of Association of Official Analytical Chemistry 16th edition. Official methods of Analysis, Washington DC, USA. 1995.

17. Egan H, Kirk R and R Sawyer Pearson's Chemical Analysis of Foods (8th ed.), Longman, Harlow, London, UK. 1981.

18. Dashman T, Blocker $\mathbf{D E}$ and $\mathbf{N}$ Baker Laboratory manual for human nutrition. Second Edition, Harwood Academic Publishers, 1996.

19. Benzie FF and JJ Strain Ferric reducing ability of plasma (FRAP) as a measure of "antioxidant power": The FRAP assay. Analytical Biochemistry1996; 239: 70-76.

20. Singleton VL, Orthofer R and RM Lamuela-Raventos Analysis of total phenols and other oxidation substrates and antioxidants by means of FolinCiocalteu reagent Methods in Enzymology 1999; 299: 152-178.

21. Lee J, Durst RW and RE Wrolstad Determination of Total Monomeric Anthocyanin Pigment Content of Fruit Juices, Beverages, Natural Colorants, and Wines by the $\mathrm{pH}$ Differential Method: Collaborative Study. Journal of AOAC International 2005; 88 (5): 1269-1278.

22. Fasoyiro SB, Babalola SO and T Owosibo Chemical composition and sensory quality of fruit-flavoured roselle (Hibiscus sabdariffa) drinks. World Journal of Agricultural Sciences 2005; 1 (2): 161-164.

23. Babalola SO, Babalola AO and OC Aworh Composition attributes of the calyces of Roselle (Hibiscus sabdariffa L). Journal of Food and Technology in Africa 2001; 6 (4): 133-134.

24. Oluwaniyi OO, Dosumu OO, Awolalo GV and AF Abdulraheem Nutritional analysis and stability studies of some natural and synthetic food colourants. American J. of Food Tech 2009; 1-7. 


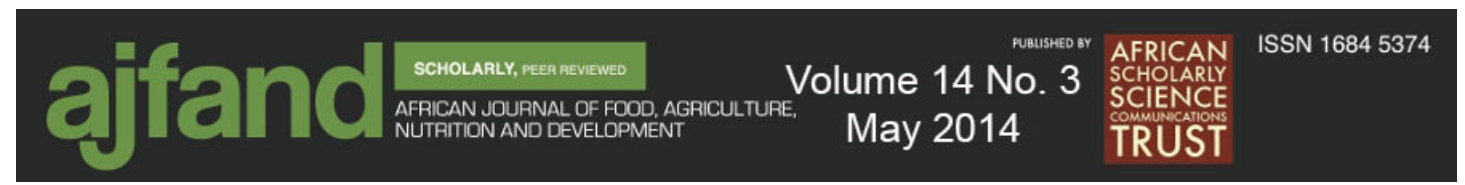

25. Odebumni EO and OO Dosumu Fermentation studies and Nutritional analysis and Drinks made from water extract of Hibiscus sabdariffa calyx (Sobo), juices of Citrus sinunsis (orange) and Ananas comosus (Pineapple). Journal of Food Technology 2007; 5 (3): 198-204.

26. Wu X, Beecher GR, Holden JM, Haytowitz D, Gebhardt SE and RL Prior Concentrations of anthocyanins in common foods in the United States and estimation of normal consumption. J Agric. Food Chem. 2006; 54: 4069-75.

27. Fang Z, Zhang M, Sun $\mathbf{Y}$ and $\mathbf{J}$ Sun How to improve bayberry (Myrica rubra Sieb. et Zucc.) juice color quality: Effect of juice processing on bayberry anthocyanins and polyphenolics. J. Agric. Food Chem. 2006; 54: 99-106. 